\title{
Dos estilhaços de uma pesquisa
}

Elisandro Rodrigues ${ }^{(a)}$

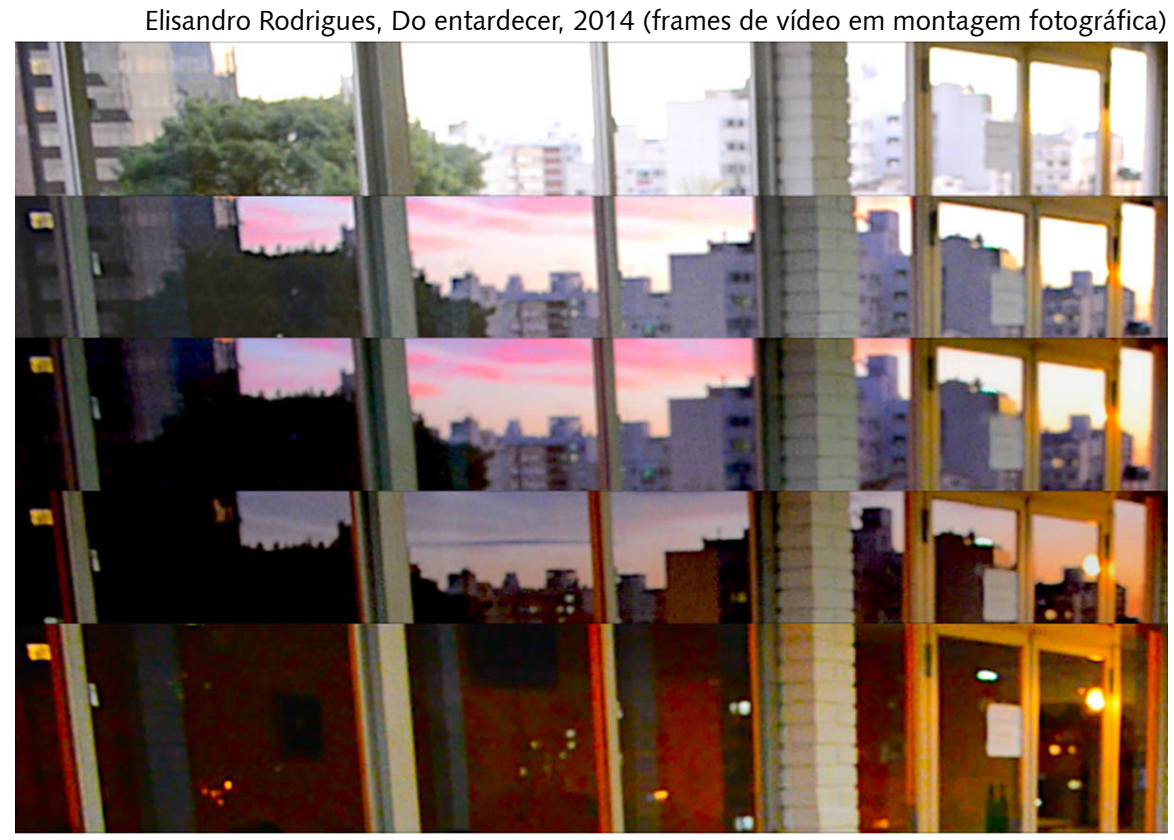

_do que se inicia nos encontros

O texto que segue é resultado da dissertação de mestrado "Clínica de uma Vida: estilhaços de educação e[m] saúde", defendida no programa de PósGraduação em Saúde Coletiva. São sete fragmentos literários, hiatos de tempo que marcaram o fazer pesquisa e o ser pesquisador compondo a entrada de cada capítulo da dissertação de mestrado. Esses fragmentos são minicontos que narram a história do Sr. Warburg e seu processo de pesquisa sobre as imagens da medicalização da vida. É uma narrativa de ficção de uma pesquisa porvir. 
Não é por acaso que a metamorfose da lagarta e da ninfa em borboleta é chamada de imago. Assim se passa da borboleta e com a imago psíquica no sentido de Lacan (ou de Merleau-Ponty, aliás): ela bate - ela bate as asas. É uma questão de aparição visual e de experiência corporal ao mesmo tempo ${ }^{1}$. (p. 2)

6 am

O Senhor Warburg abre os olhos. Olha para o relógio ao lado de sua cama. São seis horas. Levanta rápido, com a rapidez com que consegue se movimentar. Um velho de 75 anos já carrega as marcas do tempo em seu corpo. Faz meses que o Senhor Warburg planeja esse dia [Chamaremos o Senhor Warburg apenas de Sr. W., para facilitar nossa história e leitura] ${ }^{(b)}$. Faz vinte e quatro meses, setecentos e vinte e nove dias que ele vem planejando esse momento. Ele pensa se são esses os dias, ao lavar o rosto e ao olhar-se no espelho. Já na cozinha prepara ritualisticamente seu café. Duas colheres pequenas de café, enche a cafeteira italiana de água, lembrando de não ultrapassar a marca de segurança, já apagada pelos anos de uso. Coloca a água para ferver em fogo baixo. Enquanto o café emerge pelo mecanismo até o topo, prepara duas fatias pequenas de pão. Senta na pequena mesa da cozinha e, silenciosamente, come. Escuta-se apenas o sorver do líquido na xícara e as mordidas no pão já um pouco seco. Na sua mente, a organização do dia desfila passo a passo. 'Levantar às seis horas. Ok. Tomar o café. Ok. Passar a manhã organizando os materiais necessários para o trabalho. Retomar, item a item, o que será necessário. Almoçar por volta das 11 horas. Tirar uma sesta até as 14 horas. Retomar anotações e organizar por ano e mês os conteúdos e informações. Sair para tomar um café, por volta das 17 horas. Voltar pra casa e terminar o projeto já iniciado'. O Sr. W. sabe que tem de ser meticuloso em seu cronograma. Hoje é o dia setecentos e trinta, hoje é o dia em que ele termina. O Sr. W mantém seu cronograma até antes das 16 horas. Pela energia acumulada e sua prévia organização, consegue liberar-se antes para o café da tarde. Decide usar o intervalo de tempo para tomar um ar fresco no parque. Coloca seu sobretudo, pega seu cachecol e seu chapéu. O parque fica a poucos minutos de caminhada de sua casa. No caminho, vai retomando a lista mental e enumerando o que já foi realizado, vendo se não esqueceu de nada. O Sr. W. é meticuloso e, ao longo dos ano, criou o costume de realizar anotações do que vê e do que lê em um pequeno bloco que carrega consigo. Muitas das anotações são mentais, e, com o passar dos dias, ele acaba esquecendo, não lembrando o que aquelas poucas palavras escritas querem dizer, ou o porquê da anotação. Sentado no parque, observa o movimento das pessoas e das borboletas ao redor. O Sr. W. sempre gostou de borboletas. Quando criança tentou ser colecionador. Conseguiu catalogar algumas espécies com a ajuda dos livros especializados no assunto. Como não dispunha de equipamentos para mantê-las organizadas, alfinetadas e intactas, tirava fotos para o seu livro de registro. Fazer essa captura de imagem sempre foi difícil. Quando conseguia uma pose decente, tinha de torcer para o filme não queimar. Ser colecionador, pesquisador de borboletas tornou-se muito complicado. Abandonou seu hobby menos de um ano após o seu início. Olhando o voo das borboletas, faz uma anotação, rabiscando em seu bloco palavras soltas: 'As imagens são como as borboletas, esperam o tempo certo para alçar o voo. Primeiro, devem ser concebidas: as borboletas no acasalamento; as imagens, no pensamento, na imaginação. A borboleta coloca o ovo sobre a superfície de uma folha, tem de torcer para que eles não sejam devorados por algum inseto ou animal. Depois de algum tempo, o ovo eclode e de dentro sai uma pequena larva, uma lagarta. Nessa condição, ela vai viver a maior parte de sua vida, trocando (b) Utiliza-se aqui o nome Warburg não apenas como ficção. Aby Warburg foi um Historiador da Arte alemão (1866-1929), conhecido como o pai da Iconologia moderna. Sua grande obra é conhecida como Atlas Mnemosyne, sua história da arte sem imagens, sua iconologia dos intervalos por meio da montagem de imagens que dialogam entre si. São 79 painéis, reunindo cerca de 900 imagens, todas são reproduções de obras, pinturas, gravuras, recortes de jornais, selos postais. Ao montar essas imagens, Warburg colocava os painéis um ao lado do outro, para que elas pudessem entrar em diálogo. Ao pensar nos hiatos de tempo produzido pela leitura e a escrita da dissertação de mestrado, optou-se por criar vazios literários, de uma forma ficcional construindo um Atlas de Imagens da Medicalização da Vida, assim como o Atlas Mnemosyne de Aby Warburg. Para saber mais sobre a biblioteca de Warburg e o sobre seu Atlas, acessar http://warburg.library.cornell.edu/. 
várias vezes de pele e crescendo. No momento certo, será envolta por si mesma, em sua pupa, ninfa - ou crisálida -, fase intermediária entre a larva e o nascer. Permanece, então, em silêncio, esperando. A imagem nasce de sua fabricação, de sua imaginação, às vezes, prolonga-se no seu nascer, vai se modificando conforme amadurece o pensamento, conforme as experiências da vida vão se colocando no seu corpo. Por vezes, silencia por uma noite, por vários meses, até que, de súbito, uma nova imagem explode, cintila por um breve instante antes de levantar voo e desaparecer novamente. Imago é o instante em que a borboleta sai de sua crisálida. Quem sabe, um dia, essa borboleta, ou essa imagem, volte até nós novamente'. O Sr. W. permanece ainda com seu pequeno bloco de anotações aberto, olhando para os passantes e viventes. Vagarosamente, guarda suas memórias junto ao bolso do casaco, no lado esquerdo, e sai caminhando rumo ao centro da cidade.

Se numa certa noite, por um feliz acaso, a grande borboleta retornar a nós, atraída pela chama de uma vela, e se acontecer de, ao aproximar-se por demais da chama, ela se tornar cinzas, ainda assim a borboleta permanecerá na memória. As cinzas continuaram vivas, incandescentes, luminosas. Bastará um simples sopro para reavivar o fogo, reencontrar a borboleta com olhos de coruja que se esconde no meio delas. A imagem $\operatorname{arde}^{2}$. (p. 62)

\#

\section{$17 \mathrm{pm}$}

O Sr. W. tem o costume de escolher lugares diferentes para tomar seu café. Tem alguns preferidos, que, de fato, fazem 'café de verdade', e outros aonde vai só por experimentação ou pela comodidade do percurso. Hoje, ele quer algo especial, não precisamente um 'café de verdade', mas uma imagem que invada seu pensamento. Para o Sr. W., um café tem de ter sabor, aroma, textura, ser bem feito e bem tirado. Não pode ser uma água escura que evoca uma mera lembrança. Uma imagem lembrança do que é um café é o que, muitas vezes, aparece na mesa de Sr. W. Hoje, ele não vai pelo líquido. Vai pelo olhar. Os pensamentos parecem fabricar muitas imagens nesse percurso, e ele caminha olhando para o chão e pensando nas superfícies, nesse chão que berra histórias e em seus próprios atos de olhar. Chega até o antigo hotel, que antigamente acolhia as culturas viajantes, e que, hoje, se inverte e faz a cultura viajar, que irrompe à passagem do olhar, por vezes permanece e, em outras, evanesce. Entra no elevador, solitário. Aperta o botão com o número sete. A porta se fecha. A máquina de elevação, na vertical, sobe suavemente. A porta se abre. Ele sai. Caminha alguns passos e outra porta se abre. Entra. Olha para os cantos à procura de uma mesa vazia. No canto direito, enxerga uma que lhe serve, longe do único casal que ocupa o local. A mesa tem uma vista quase perfeita, para o horizonte onde o lago brota por entre matos e concretos. Infelizmente, entre seu olhar e as águas, monumentos de concreto erguem-se. Em cima da porta de entrada, um relógio marca 17 horas. O sol caminha a passos lentos, esquentando o que resta de um dia. Pede um café. Abre um livro. O Sr. W., além da chave de casa, de sua carteira com os documentos e dinheiro, de seu bloquinho de anotações e seu lápis de escrever pensamentos, sempre carrega consigo um livro. A capa do livro que carrega nesse dia poderia ser vista pelo casal que compartilha o mesmo espaço. Têm um título que sobressai logo abaixo de uma máquina antiga de projetar filmes - 'Homem no Escuro', de Paul Auster. O Sr. W. parece ler, mas seu olhar foge repetidas vezes das páginas do livro. Fica minutos a olhar o longínquo. Foi para isso que ele veio a este local, para deixar os olhos fugirem da superfície. Os minutos caminham e o sol segue seu curso, deitando cada vez mais. Seu pensamento parece voar para lugar nenhum. Dois casais entram, falando alto. Em cima da porta, os ponteiros marcam 17 horas e 50 minutos. O sol começa a querer se esconder por trás da vegetação e das águas. Aos poucos, vai colorindo o final do dia com uma tonalidade que mistura o laranja e o vermelho. O Sr. W. olha para essa imagem e pisca algumas vezes, como se seus olhos fossem máquinas fotográficas tentando captar aquele momento. O Sr. W. nota, nessa coloração, a presença forte do azul - um alaranjado azulado. Ele levanta. Paga o café e sai. Lá embaixo, a noite começa tímida, com tons de vermelho. O frio que vem do lago obriga-o a fechar o casaco e puxar a gola para cima. No horizonte, as tonalidades ainda permanecem. Do lado oposto, a cortina da noite é puxada por pequenos pontos que brilham. $\mathrm{O}$ azul noite prevalece na disputa das cores. A noite devora silenciosamente o dia. O Sr. W. segue o caminho de casa. 
CRIAÇÃO

A noite

me pinga uma estrela no olho

e passa ${ }^{3}$. (p. 91)

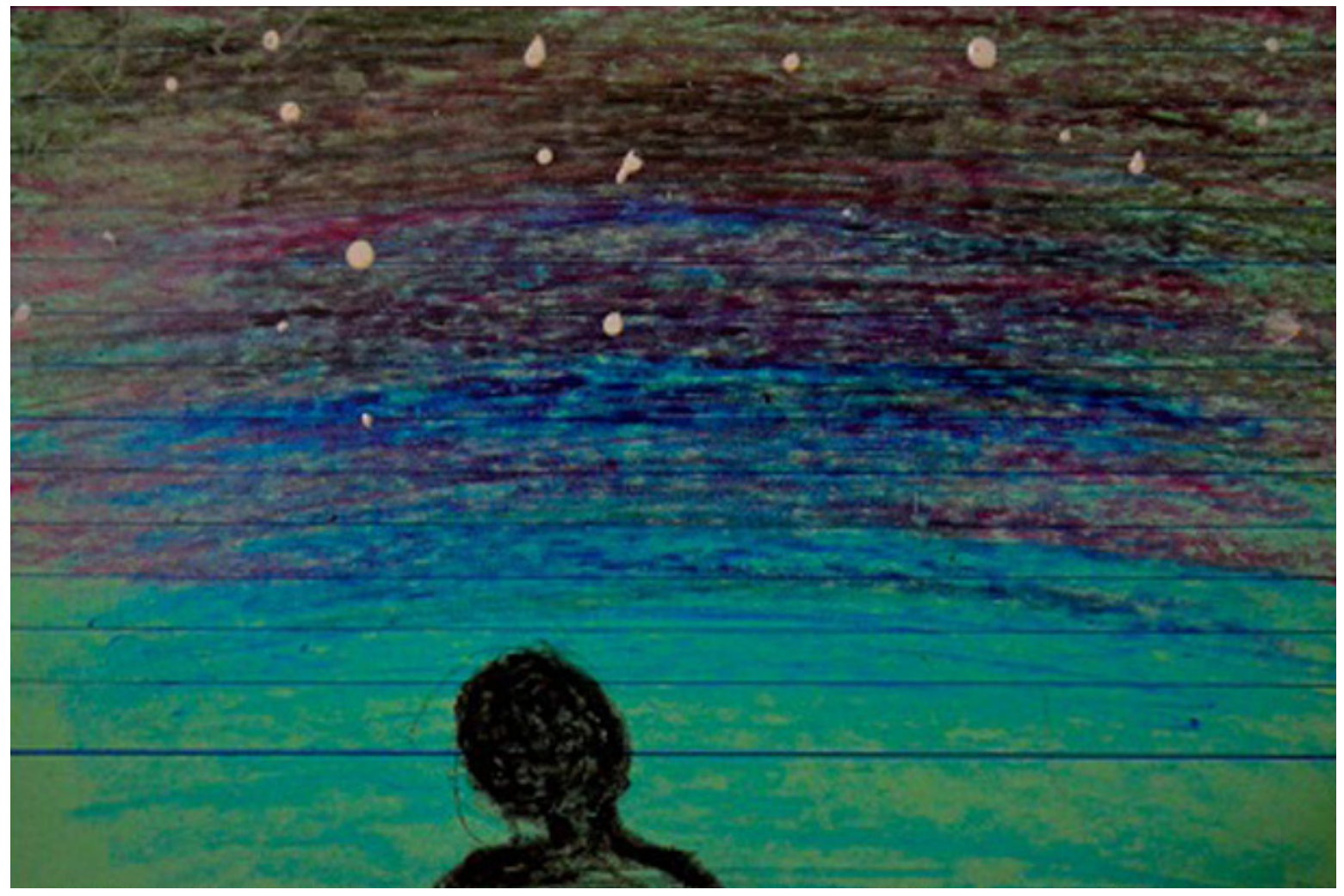

Guilherme Santos Torres, 2014, desenho com giz e caneta colorida

472 (อ) Interface comunicaçäo saúde educação 2017;2l(61):469-80 
(c) O nome Georges, utilizado aqui como um confidente do Sr. W., é um nome ficcionado com 0 de Georges DidiHuberman, filósofo e historiador de arte que vem pensando a complexidade das imagens, suas dimensões éticas e políticas. Didi-Huberman um leitor de Aby Warburg o qual dedica um livro sobre o pensamento e a montagem anacrônica das imagens e do tempo (Para sabe mais: A imagem Sobrevivente. História da arte e tempo dos fantasmas segundo Aby Warburg. Rio de Janeiro: Contraponto, 2013).

(d) Imagens 1 a 3 retiradas da internet dos seguintes endereços, Imagem 1 - Xarope Divino e Imagem 3 - Anúncio dos produtos Tayuya, sabão Aristolino e xarope Grindelia - http://lounge. obviousmag.org/ anna_anjos/2012/11/ publicidades-antigasdo-brasil.html

Imagem 2 - Anúncio de 1939 - http:// tokdehistoria.com br/tag/anuncios/, Imagem 4 - Geniol - http://www.

amenidadesdodesign com.br/2014/03/acabeca-de-geniolquando-publicidade html.
19 pm

O Sr. W. olha para a organização que fizera na parte da manhã e da tarde. Está tudo preparado. As anotações estão em um lado, perto dos livros a serem usados. As imagens estão no centro, perto dos dez quadros pretos enfileirados um atrás do outro. O Sr. W passou dois anos pesquisando e organizando todo o material para esse dia. É o dia em que irá, enfim, montar e colar as imagens. Foram dois anos dentro de velhos livros, antigas imagens, vários cadernos de anotações e pensamentos, do vasculhar na internet à procura de referências. De leituras, desleituras. Conversas, imagens encontradas e pensadas que, algumas vezes, o levaram a bifurcar seu caminho nesses setecentos e trinta dias. Olha para o material novamente. Seus pequenos cadernos são enumerados, iniciando no número um até o número 12, o que ele carrega no bolso no momento. O caderno número sete é onde se encontra a estrutura de sua pesquisa. Olha as anotações: 'cem fotos. cem anos. cem fatos. cem acontecimentos. cem histórias recontadas a partir de imagens. cem palavras não ditas'. O trabalho que ocupou Sr. Warburg nesses dois anos foi o de coletar imagens-acontecimentos. Chegou a hora de montá-las e finalizar essa história imagética. Ele pega o caderno de número três e começa a ler uma das anotações 'Como contar cem anos de história por meio de imagens? Como escolher um acontecimento por ano? Mas contar o quê?'. Em outra folha, lê: 'Hoje em conversa com Georges ${ }^{(c)}$, pensei que talvez pudesse catalogar cem imagens que digam de um acontecimento específico, buscar imagens de um processo histórico e social. Georges me perguntou o que me inquietava, o que não estava na superfície do meu olhar. Demorei a responder a essa pergunta. E não respondi'. O Sr. W. olha para o centro, onde as imagens estão todas juntas, e fala baixinho consigo mesmo - 'Reuni trezentos imagens sobre medicalização da vida'. Caminha até o canto, onde encontra-se sua velha vitrola, escolhe o disco de Blind Willie Johnson e o coloca para tocar. Senta perto das imagens, puxa os caderninhos e anotações sobre as imagens, e, conversando consigo mesmo, enuncia aos montes de palavras e imagens - 'vamos lá, preciso separar, escolher, de trezentos imagens, apenas cem, e agrupar essas cem em dez blocos de dez imagens, cada bloco imagético irá acompanhar dez anos. dez blocos, cem anos'. Em algum lugar um relógio badala sete horas. Lá fora, o azul toma conta da noite.

\section{\#}

\section{$22 \mathrm{pm}$}

O Sr. Warburg está inquieto nos últimos minutos. No corpo, sinais de incômodo, a dor começa em partes específicas, nas costas e pernas. Muito tempo sentado. Faz três horas que está trabalhando sem parar. 'Mereço um intervalo', pensa consigo mesmo. O Sr. W. levanta-se de sua poltrona. No chão, estão as imagens separadas em dois montes, as que serão usadas, cem imagens, e outras que, nesse momento, não entram na composição dos pensamentos. Três quadros estão montados em pé, como uma tela de pintura. Nesses quadros, imagens estão dispostas, afixadas com um pequeno alfinete. O Sr. W, ao levantar, fica encarando as telas prontas. As mãos fazem massagem na lombar. Os olhos captam as histórias não ditas naquelas imagens. Ao separar as imagens, o Sr. W. pensou que seria mais fácil fazer a composição, a montagem que se encontra à sua frente. Separá-las foi teoricamente fácil. Atrás de cada imagem havia uma anotação: o ano e a situação, o acontecimento a que aquela figura se referia. Difícil foi quando percebeu que não tinha exatamente dez imagens por década, ou uma para cada ano. Dessa forma, 
teve de organizar as imagens em blocos que contassem a década apenas, e não uma imagem a cada ano. No primeiro quadro encontram-se sete imagens; no segundo, oito imagens, e, no terceiro, 11 imagens. Trinta anos já estão compostos, montados. De 1925 a 1945. O Sr. W pega o caderninho de anotações com o número seis na frente, passa as páginas lentamente, à procura de uma anotação - 'Ao observar as imagens, todas elas contêm palavras, mostram-se como um problema. Como contar os últimos cem anos imageticamente sobre a medicalização sem usar palavras, se a maioria das imagens vinculam palavras? Seriam frases-imagem?'. Fecha seu caderno de anotações e olha novamente para os painéis prontos. Poucas dessas imagens foram tiradas no Brasil. Entre as imagens em preto e branco à sua frente, algumas destacam-se. São fragmentos de uma história. Cascas de um acontecimento. Observa algumas imagens ${ }^{(d)}$, duas no painel que vai de 1924 a 1929. Uma imagem mostra uma pomba com raios saindo dela em todas as direções, em cima o nome do medicamento 'xarope divino'; ao lado, palavras escritas com nomes de doenças e, logo abaixo, o dizer: 'não há remédio igual'. A outra imagem mostra três mulheres, ao redor uma iluminação, próxima ao "divino", ao milagre, da imagem anterior. Uma propaganda de dois remédios ao mesmo tempo, um xarope e um sabão. Produtos mostrados como milagrosos no combate aos sintomas e doenças. Em outro painel, uma imagem composta de palavras, datada de 1939. Na imagem, uma mulher vestida com uma blusa preta, realçando os seios, com os dizeres: 'Magros de nascença podem agora obter $2 \mathrm{~kg}$ numa semana'. Não aparece o nome do produto, apenas a frase. Durante a pesquisa das imagens sobre medicalização, o Sr. W. achou muitas referindo-se a medicamentos e remédios. Algumas, como essa última, mostrando uma outra forma de subjetivação. Em seu arquivo, chegou a organizar imagens de várias décadas sobre o mesmo remédio ou medicamento. É o caso da imagem no terceiro painel, um clássico da propaganda farmacêutica da Argentina. A imagem mostra a caricatura de uma pessoa sorrindo, na cabeça muitos pregos, anzóis, alfinetes. O efeito milagroso do 'Geniol' acaba eliminando a dor de cabeça. 'Como gostaria de um genial agora', comenta o Sr. W., observando a careca sorridente. Estica o corpo. Caminha um pouco pela biblioteca. Coloca lenha na lareira. Olha o monte de imagens no chão e volta a sentar em sua poltrona.

Pelo termo frase-imagem entendo a união de duas funções esteticamente por definir, isto é, pela maneira como desfazem a relação representativa da imagem pelo texto. No esquema representativo, a parte do texto era a do encadeamento ideal das ações, a parte da imagem era a do suplemento de presença que lhe dá carne e consistência. A frase-imagem derruba esta lógica. No seu seio, a função-frase é sempre a do encadeamento. Mas, doravante, a frase desencadeia-se, tanto que é ela que dá carne. E esta carne ou esta consistência é, paradoxalmente, a da grande passividade das coisas sem razão. ${ }^{4}$ (p. 65) 

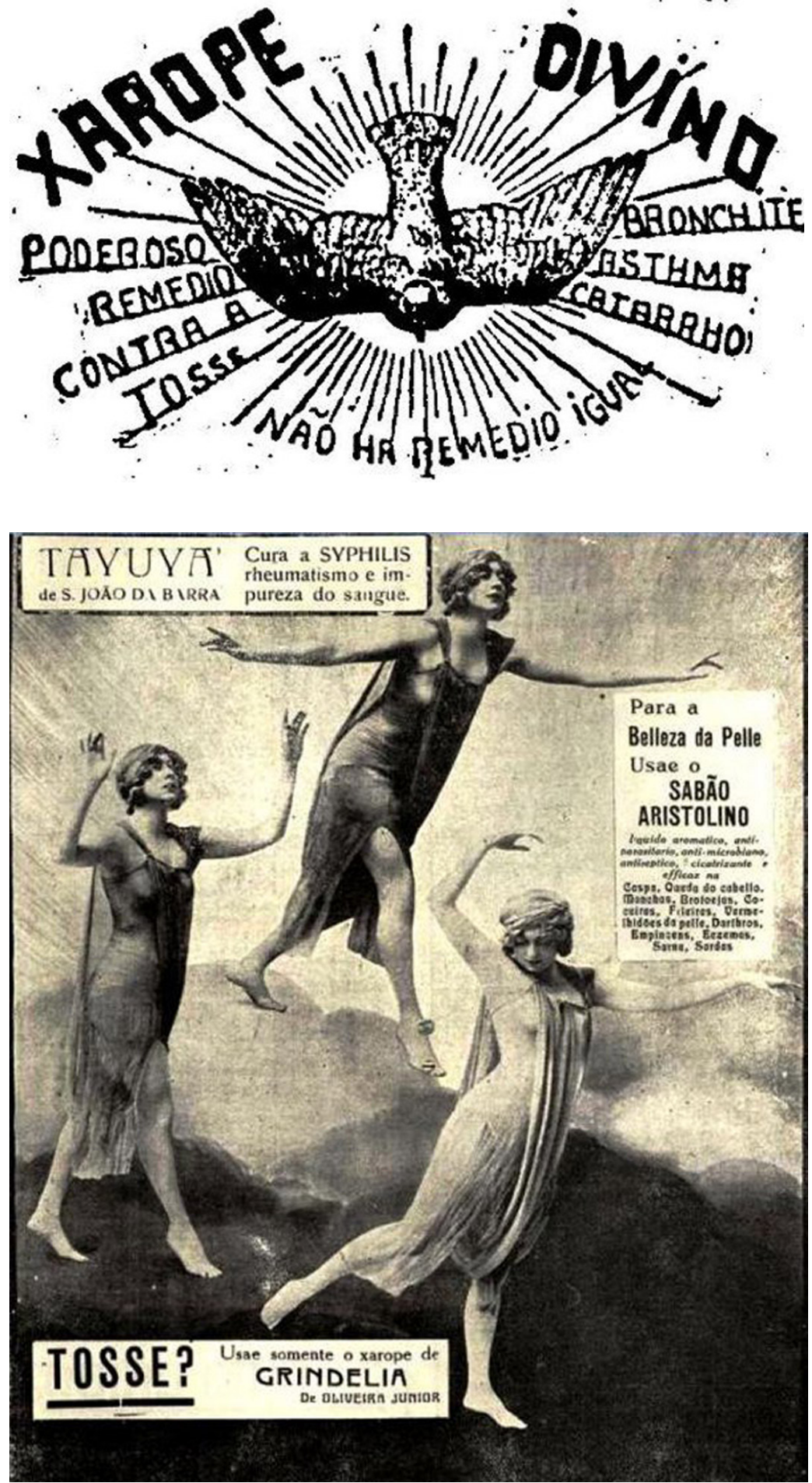

DE JUNHO DE 1939

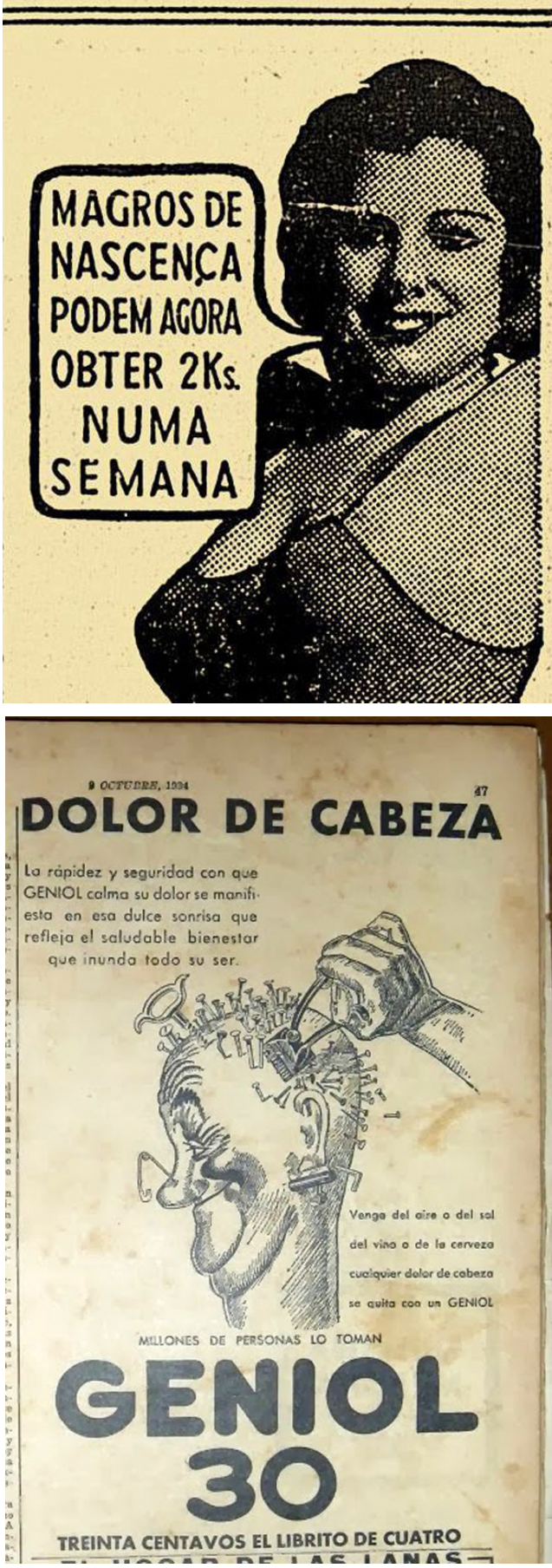

Anúncio dos produtos Tayuya, sabão Aristolino e xarope Grindelia, internet

Geniol, internet 


\section{0 am}

O cansaço e o sono começam a pesar nos olhos do Sr. W. Os olhos piscam rapidamente, várias vezes. Em algumas piscadelas, permanecem um instante fechados. 'Um café viria bem agora' - pensa, consigo mesmo. O Sr. W. levanta e caminha até a cozinha. O cheiro do café novo sendo passado espalha-se pela casa, invadindo os cantos e despertando os sonos adormecidos. Um cheiro na meianoite. 'Foi-se o tempo em que conseguia aguentar a noite toda acordado' - o Sr. W. pensa nos tempos de juventude - 'Conseguia virar a noite, lendo, estudando, escrevendo, corrigindo provas e trabalhos'. Resmungando para si mesmo, sorve o café em pequenos goles. O projeto de construir um mapa imagético dos últimos cem anos, de uma história sem palavras, sobre a medicalização da vida, vagou no pensamento do Sr. W. por uns 15 anos. O tempo, como sempre, era curto. Aulas. Seminários. Correções. Viagens. Projetos da Universidade. Bancas. Ao pensar em sua aposentadoria, com seus setenta anos, decidiu retomar esse velho pensamento. Mas, antes, necessitava descansar, prepararse para isso. Tirou um ano para organizar seu tempo de professor, para despedir-se vagarosamente do ensino. Das orientações. Rever anotações. Artigos. Traduções. Mais um ano para desligar-se gradativamente dos afazeres acadêmicos e, por fim, um ano sabático. De viagens por lugares que ainda não havia visitado, de revisitar seus lugares preferidos, de passar um tempo com os contatos da Paris VIII, da Escola de Altos Estudos em Ciências Sociais de Paris. De tomar cafés nos finais de tarde com os professores, conhecidos da Alemanha, Bélgica, Holanda, EUA. Um ano para amadurecer seu projeto por meio de diálogos. O Sr. W larga a xícara e volta para sua biblioteca. Olha para os cinco painéis já prontos. Um trabalho de dois anos. De escavação. De memória. De estilhaçar o tempo à procura de instantes. Olhando para as imagens dispostas nos painéis, fica a pensar nas perguntas que o acompanharam ao longo dos últimos anos: 'O que o outro, ao olhar essas imagens, irá pensar? Será que as imagens farão brotar pensamentos? No que elas farão pensar?'. O Sr. W. sabe que não tem essas respostas, e que dificilmente vai ter, a menos que alguém lhe escreva criticando, elogiando, contrariando, duvidando. Mas, até lá, o olhar é apenas o dele, e as possíveis respostas também. Mas ele sabe também que cada imagem, cada composição diz uma coisa e, ao mesmo tempo, várias coisas. Cada instante, acontecimento, poderá ser interpretado, se o observador deixar que a imagem fale com ele, ao se colocar diante dela. Cada interpretação, diferente uma da outra... 'O que vemos quando algo nos olha?', pensa alto. O Sr. W. vai até a janela e fica alguns instantes a fitar, por trás do vidro, a noite. Pensa, ou imagina, ver alguns pontos brilhantes a se apagarem e acenderem. Brilhando aqui. Brilhando mais adiante - 'Será que são vaga-lumes?'. Tenta fixar o olhar para ver outros pontos luminosos na noite. Nada vê. 'Uma imagem vaga-lume, apenas de passagem'. Decide acender a lareira para ver crepitar, dentro da sua biblioteca, os pequenos vaga-lumes. O cheiro do café ainda permanece na casa. Vai sendo levado para a noite como um gosto de perguntas despertas.

\section{\#}

\section{4 am}

Tento olhar, mas não consigo mais enxergar. Levanto as mãos, trazendo-as próximo ao rosto. Não as vejo. Apenas as sinto. Sinto a penumbra ao meu redor. Olho para todos os lados. Só vejo escuridão. Será que ainda continua noite? Será que ainda estou dormindo, com aquela sensação de estar acordado, de não conseguir acordar do próprio sonho? Tento mexer o resto do corpo. Os membros obedecem. Fecho e abro os olhos, repetidamente. Tudo continua noite. Tudo é escuro. Me desespero. Tento sair da cama e não acho mais minhas roupas. Não me lembro onde estão meus óculos. Deve ser isso. Meus olhos fraquejam a cada dia. Tateio ao redor até achar a cômoda. Sinto os óculos. Fecho os olhos e os mantenho assim por um tempo. Coloco os óculos. Não vejo nada. Só vejo a escuridão. A casa aumenta. Já não sei mais onde as minhas coisas estão. Saio nu a caminhar, tateando as paredes em busca do interruptor. O ar parece mais frio. Meu corpo se arrepia todo. Paro a escutar. Rangidos. Zumbidos no ar. Roço no que parece ser uma planta. Paro novamente. Estalido da madeira. O medo cresce. Será que tem alguém na casa? Devo gritar? Dizer que não enxergo? Não. Pode ser um ladrão 
a espreitar. Tudo parece ser tão gigante no escuro. As sensações parecem aumentar. Continuo tateando o escuro, à procura de algo ou alguém. Lembro que estou sozinho. Os olhos lacrimejam. De dor? De medo? De forçarem para ver? Grito. "Tem alguém aí?". Escuto a resposta: "ai". "ai". "ai". Meus joelhos tremem. Meu corpo despenca. O chão me acolhe, com um baque surdo. O barulho do corpo, ao tocar o chão, ecoa pelos corredores. Minha pele sente o frio do piso. Passo a mão à volta. Sinto os ladrilhos. Já não me lembro de sua forma e cor. Tento olhar, mas não consigo enxergar. As imagens começam a desaparecer.

O Sr. W. acorda. O coração parece querer saltar do peito. Um sonho. Melhor, um pesadelo - pensa o Sr. W. recompondo-se. Olha para o relógio, em cima da mesinha de canto. '04 horas. Devo ter adormecido por quase uma hora'. Levanta. O pescoço dói. Lembra que estava com a cabeça caída para trás em sua poltrona. Olha para os painéis. Oito estão finalizados e o nono está pela metade. Rapidamente, passa por sua cabeça que deveria descansar mais um pouco, terminar pela manhã. 'Falta pouco, vou terminar logo'. As imagens no chão diminuíram. No monte, só restam algumas a serem usadas. Caminha até a lareira, assopra as brasas ainda vivas para reativar o pequeno fogo, acrescenta mais lenha. Desloca-se até a cozinha. Toma uma água e volta para suas imagens e painéis.

\title{
\#
}

\begin{abstract}
06 am
'Dia trezentos e trinta e um.' O Sr. W escreve em uma folha, continua: 'Georges, desde ontem à noite me encontro aqui. Daqui a pouco, o dia amanhece'. Olha a sua volta, tudo está organizado. Os livros usados estão nas estantes que preenchem as paredes de sua biblioteca. Os cadernos de anotações continuam empilhados sobre a mesa. As imagens não usadas, nos painéis dentro de um arquivo preto. Os dez painéis pretos, montados, contendo cem imagens dos últimos cem anos, divididos de 1925 a 2015. Dez painéis imagéticos. Imagens de jornais, de revistas, anúncios, propagandas de medicamentos. Xerocados, fotografados, contendo palavras e imagens, ou apenas imagens. Tudo pronto. Finalizado. Dois anos de pesquisa organizados. 'Agora', pensa o Sr. W., 'resta fotografar os murais, separar as imagens escaneadas no computador para montá-las virtualmente e concluir meu atlas sobre a medicalização'. O Sr. W. olha pra tudo com um sorriso no rosto. Olha para fora, pela janela embaçada. Aproxima-se dela, limpa o vidro com a ponta do casaco para ver o lado de fora. A cerração impede um pouco a visibilidade, mas, por entre a opacidade, enxerga um céu azul. O azul toma conta da noite e do dia que se anuncia. O Sr. W. lembra da cena de um filme de que não consegue lembrar o nome. A cena que lhe vem à memória é de duas jovens mulheres que vivenciam um momento antes do nascer do sol, captam com seus silêncios a hora azul. Momento de tranquilidade, de suspensão no tempo. O Sr. W. volta a se sentar e continua sua carta: 'Acabo de olhar pela janela e estamos naquele momento que é entre o final da noite e o amanhecer, alguns o chamam de hora azul. Tudo é silêncio. Pouco se escuta. Ontem à noite pensei ter visto vaga-lumes por perto. Lembrei-me muito de uma noite que passamos juntos, era alta madrugada e caminhávamos bêbados pelas ruas de sua cidade, avistamos alguns pontos luminosos voando e piscando aqui e ali no meio da rua, começamos a correr atrás dessas luzes e nos deparamos com um bosque cheio de vagalumes. Lembras? Foi tão bonito ver aquele baile de luzes na noite...Georges, te escrevo para dizer que terminei meu projeto. Junto com essa carta, seguem os painéis para tua análise. Espero te encontrar logo. Abraços afetuosos. Warburg'. O Sr. W. descansa a caneta sobre o papel. O sono da madrugada passou. Seu pensamento está a todo vapor. Decide caminhar um pouco. Logo, o dia começa a clarear. Caminha em direção à porta. Coloca seu sapato, pega seu casaco, seu chapéu e sai para a rua. Lá fora, a noite se despede aos poucos, a cerração impede a visão e molha o casaco do Sr. W., as gotículas de água que caem criam pequenas lágrimas sobre as folhas. Os passos do Sr. W. ecoam na opacidade da noite que logo será dia.
\end{abstract}


CRIAÇÃO

\section{Referências}

1. Didi-Huberman G. Imaginer, disloquer, reconstruire, in Histoire de l'art et anthropologie [Internet]. Paris: INHA, Musée du quai Branly; 2009. [Citado 27 Jul 2009]. Disponível em: http://actesbranly.revues.org/193

2. Samain E. Como pensam as imagens. Campinas: Ed. da Unicamp; 2012.

3. Leminski P. Toda poesia. São Paulo: Companhia das Letras; 2013.

4. Rancière J. O destino das imagens. Rio de Janeiro: Contraponto; 2012. 
Essa é uma escrita de estilhaços e fragmentos literários presentes na dissertação "Clínica de Uma Vida: estilhaços de educação e[m] saúde", defendida no Programa de Pós-Graduação em Saúde Coletiva da Universidade Federal do Rio Grande do Sul. A composição - colagem - montagem da escrita se dá por meio de minicontos ficcionais que narram a história do Sr. Warburg e seu processo de pesquisa sobre possíveis imagens de medicalização da vida. Uma ficção que versa sobre medicalização e clínica; processos de ensino e aprendizagem; educação e saúde coletiva, permeadas por palavras-imagens que inquietam o pensamento.

Palavras-chave: Clínica de Uma Vida. Medicalização da vida. Educação em Saúde. Imagem.

\section{Bits and pieces of a research}

This paper consists of literary passages and fragments from the masters' dissertation "Clinic of a Life: bits and pieces of education (in) and health", presented in the Postgraduate Program in Collective Health at the Federal University of Rio Grande do Sul. The composition - collage - assembly of this writing encompassed fictional short tales narrating the story of Mr. Warburg and his process of research about possible images of the medicalization of life. It is a fictional work addressing medicalization and clinic; teaching and learning processes; education and collective health, pervaded with thought-disrupting image-words.

Keywords: Clinic of life. Medicalization of life. Education in health. Image.

\section{De los fragmentos de una investigación}

Este es un escrito de residuos y fragmentos literarios presentes en la disertación: "Clínica de una vida: fragmentos de educación y [en] salud", defendida en el Programa de Postgrado en Salud Colectiva de la Universidad Federal de Rio Grande do Sul. La composición - collage - montaje del escrito se realiza por medio de mini-cuentos ficcionales que narran la historia del Sr. Warburg y su proceso de investigación sobre posibles imágenes de medicalización de la vida. Una ficción que trata sobre medicalización y clínica, procesos de enseñanza y aprendizaje, educación y salud colectiva, traspasadas por palabrasimágenes que inquietan el pensamiento.

Palabras clave: Clínica de una vida. Medicalización de la vida. Educación en salud. Imagen 


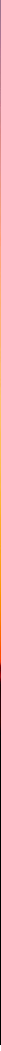

